\title{
Intellectual values and epistemological understanding of middle school students in Indonesia
}

\author{
Ika Andrini Farida ${ }^{1}$, Dewi Retno Suminar ${ }^{2}$, Nur Ainy Fardana Nawangsari ${ }^{3}$ \\ ${ }^{1,2,3}$ Faculty of Psychology, Universitas Airlangga, Indonesia \\ 1ika.andrini.farida-2014@psikologi.unair.ac.id; ${ }^{2}$ dewi.suminar@psikologi.unair.ac.id; \\ ${ }^{3}$ nurainy.fardana@psikologi.unair.ac.id
}

\section{ARTICLE INFO}

Article history

Received 01 November 2019

Revised 01 June 2020

Accepted 02 June 2020

\section{Keywords}

epistemological understanding intellectual values

middle school students

\begin{abstract}
Engaging in intellectual activities and seek new knowledge is critical for Indonesian students. However, most learning activities in elementary and secondary schools in Indonesia are centered on rote learning. This study aimed to provide an initial description of how middle school students in Indonesia value intellectual activities and describe the level of epistemological understanding that underlie how they value intellectual activities. Sixty-eight middle school students were involved in this study by giving their responses to intellectual values questions. Descriptive analysis was conducted to examine the percentage of participants who endorse discussion. Additionally, the reasons for endorsing discussion were also examined to determine the epistemological understanding level. The percentage of participants that endorse discussion in question one, two, and three was $71 \%, 47 \%$, and $50 \%$, respectively. While $24 \%$ of participants consistently endorsed discussion in all three questions. Most students gave reasons that indicate absolutist or multiplist level of an epistemological understanding. Very few reasons can be categorized into the evaluativist level. Students seem to believe that discussion is important to do to solve the problems. Most students have yet to perceive the intellectual activity as an essential tool to enhance their understanding and acquire new knowledge, as an evaluativist would.
\end{abstract}

\section{Introduction}

The most critical mission of education is to teach students how to think and learn, equipping them with the necessary knowledge and skills to thrive as an adult (Kuhn, 1999; 2010). However, despite this fact, most learning activities in Indonesian elementary and secondary schools are still rote learning (Abdurakhman, 2016). Students tend to excessively use rote learning, memorizing information without understanding the meaning, due to the large number of lessons they receive. Information achieved through rote learning is not useful for students because it is not connected to other information stored in their memory (Slavin, 2014). Many countries have implemented several approaches like inquiry and discovery learning to teach students how to think. These approaches provide students with the opportunity to practice the skills to seek new knowledge (Bell, Smetana, \& Binns, 2005; Kuhn, Black, Keselman, \& Kaplan, 2000).

The ability to seek new knowledge is an essential aspect of cognitive development. According to the cognitive development theory from Piaget, the capacity to seek new knowledge arises during the formal operational stage when children develop the hypotheticdeductive reasoning and ability to think like a scientist called inductive reasoning (Bjorklund, 
2005). Many other experts also studied the ability to seek new knowledge. Kuhn $(2001 ; 2010)$ proposed a theoretical model that emphasizes the role of two metacognition components toward the capability of children to seek new knowledge. This two metacognition are meta-level knowing procedural and meta-level knowing declarative. Meta-level knowing procedural is needed to apply strategies to acquire new knowledge. Meta-level knowing declarative, specifically epistemological understanding, underlie the development of intellectual values that determine whether knowledge-seeking is perceived as worthwhile. Hence, meta-level knowing declarative is increasing one's tendency to learn.

This study focused on exploring the intellectual values and epistemological understanding that determine the desire to engage in intellectual activities for knowledgeseeking goal. Intellectual values describe ones' belief that intellectual activities are worthwhile (Kuhn, 2001). Despite the significance of this construct to students' cognitive development, however, only a few studies have explored it. Limited literature is available regarding the development of intellectual values in children or adolescents, as well as how it relates to other variables. A possible explanation for this is that some constructs were meant to explain the similar psychological characteristics as intellectual values such as the need for cognition, typical intellectual engagement, and epistemic curiosity.

The need for cognition is defined as one's tendency to engage in and enjoy challenging cognitive activities (Cacioppo, Petty, \& Kao, 1984; Hevey, Thomas, \& Maher, 2012). The meaning of this construct partially overlaps with intellectual values (Kuhn \& Park, 2005). Typical intellectual engagement (TIE) is defined as an individuals' aversion or interest in activities that are intellectually demanding (Ackerman, et al. 1995; Chamorro-Premuzic, et al., 2006). TIE is more widely explored than intellectual values. Researchers have studied TIE with intellectual competence constructs (Arteche, et al., 2009), learning approaches (Stumm \& Furnham, 2012), academic performance (Chamorro-Premuzic et al., 2006), and its stability and change in old age (Mascherek \& Zimprich, 2011). Epistemic curiosity is another construct similar to intellectual values. This construct is defined as the need for knowledge that encourages individuals to learn new things, search for information, and solve intellectual problems (Mussel, 2010).

Intellectual values and its' similar constructs have common characteristics; all of them are different from intellectual competence and closely associated with personality and knowledge acquisition. One aspect that differentiates intellectual values from other similar constructs is that it is not merely an attribute of the individual but is also rooted in culture. In other words, intellectual values can also be defined as how a group of culture perceives the value of intellectual activity (Kuhn \& Park, 2005).

The level of an epistemological understanding determines the development of intellectual values. Epistemological understanding is an effort to integrate subjective and objective aspects of knowing. People receive claims about various information from many sources. Thus, people need standards or criteria to justify those claims. Criteria used for justifying a claim (subjective or objective aspects of knowing) represent the development of one's epistemological understanding (Kuhn, 2001). Epistemological understanding develops through four levels: realist, absolutist, multiplist, and evaluativist. At the realist and absolutist levels, the objective aspects of knowing dominates. Children think that something is true if it represents reality. They believe that knowledge is obtained from an external source. At the multiplist level, the changes occur, and the subjective aspects of knowing replace the objective aspects. Children begin to realize that the human mind generates knowledge. Thus, everyone is entitled to their own opinion. At the evaluativist level, adolescents or adults start to coordinate the objective and subjective aspects of knowing. They begin to understand that everyone could have their own opinions, but that the best is supported by argument and evidence. At this level, discussion, debating, and other intellectual activities are perceived to be needed to justify many 
claims. At this level of epistemological understanding, the value of intellectual activities arises and encourages people to seek knowledge (see Table 1) (Kuhn, Cheney, \& Weinstock, 2000).

Kuhn \& Park (2005) studied the intellectual values and epistemological understanding of three different cultural groups (i.e., Caucasian American, Korean, \& Japanese). Intellectual values were assessed using three questions that ask participants whether they agree or disagree with the statement, "discussion is not necessary" within the given context. They found that Caucasian Americans had the highest percentage in terms of samples who consistently support discussion in all three intellectual value questions ( $77 \%$ for parents, $52 \%$ for high school students, and $40 \%$ for middle school students). In contrast, the different percentage was found among Japanese (38\% for parents and 13\% for high school students), and Korean (8\% for parents, $10 \%$ for high school students, and $13 \%$ for middle school students). Those results indicate that there is a variation of intellectual values across cultural groups. A similar pattern between parents and students suggests that intellectual values are transmitted from parents to their children.

The evaluativist level of epistemological understanding and valuing intellectual activities have similar patterns across cultural groups. The pattern indicates that those two constructs are connected. The percentage of samples with an evaluativist level of thinking was highest in Caucasian American (82\% for parents, $70 \%$ for high school students, and $60 \%$ for middle school students). On the contrary, a lower percentage was found among Korean (40\% for parents, $24 \%$ for high school students, and 17\% for middle school students) and Japanese (12\% for parents and 19\% for high school students) (Kuhn \& Park, 2005). A previous study among the Caucasian population was also found that the percentage of eighth-grade participants showing a predominantly evaluativist level is more significant than participants showing a predominantly absolutist level (Kuhn, et al., 2000).

Indonesian students need to enjoy engaging in intellectual activities and seek new knowledge. However, no studies have specifically explained how Indonesian students perceive the value of intellectual activities. Past studies have discovered that middle and high school students in Korea and Japan, also noted as a collective society like Indonesia, have lower intellectual values compared to Caucasian American students. It indicates that Indonesian middle school students might also have similar views regarding intellectual value with Korean and Japanese students. Thus, this study is intended as a preliminary study to obtain an initial description of middle school students' intellectual values in Indonesia. This study used intellectual values questions developed by Kuhn (2001), whereby participants are asked to provide reasons for endorsing discussion. This study also determines the level of epistemological understanding among middle school students in Indonesia.

\section{Method}

\section{Participants}

A total of 68 middle school students (30 boys, 38 girls, $12-15$ old years, $M=13.74 ; S D=.89$ ) were involved in this study by giving their responses to intellectual values questions. Participants were recruited from two public middle schools in a city in the province of East Java, Indonesia. Participants gave their responses in class after permission for conducting the study was obtained from the education authorities and school principals.

\section{Instrument}

Three questions developed by Kuhn (2001) were used to assess intellectual values. The first questions state that it is unnecessary to discuss some social issues because everyone has their own opinion about it. Participants were then asked to respond whether they 'Strongly Agree, Agree, or Disagree with the previous statement. Those who disagree with the statement were additionally asked to provide their reasoning for choosing the answer. The remaining two 
questions are about political candidates (stated to be not necessary to discuss because it is a matter of personal preference) and world peace (stated to be not worth discussing because it is too difficult to solve). The complete three questions are in the Appendix. Participants who respond with Strongly Agree or Agree are noted to have low intellectual values, while those who chose to Disagree are classified as individuals with high intellectual value.

Those three questions initially developed in English. Translation into the Indonesian language was conducted after permission was obtained from the author. Two experts with knowledge in both languages and cultures evaluated the content, concept, and linguistic equivalence between the original and translated questions (International Test Commission, 2016; Jeanrie \& Bertrand, 1999). Experts suggested adapting the content of the questions so it can be understood by, and more relevant to, Indonesian middle school students. Therefore, the current researcher, together with experts, decided to discuss and replace some of the examples. In the first question (i.e., the death penalty, gun control, and medical care), the issues were replaced with other examples that are more relevant to participants (i.e., excessive use of social media, adolescent sexual involvement, and divorce). Political candidates in the second question were replaced with the chairman of school organization candidates. The questions about the nature of matters in the third question were replaced with why crimes continue to exist. The completed original and adapted questions of intellectual values measure is presented in the Appendix.

\section{Analysis}

Descriptive analysis was conducted to examine the percentage of participants who endorse discussion in each question. Further examination was undertaken to explore whether their reasoning reached the evaluativist level, refers to Kuhn, et al. (2000). Table 1 summarizes epistemological understanding develops through four levels: realist, absolutist, multiplist, and evaluativist.

Table 1

Levels of Epistemological Understanding

\begin{tabular}{clll}
\hline \multicolumn{1}{c}{ Level } & \multicolumn{1}{c}{ Assertions } & \multicolumn{1}{c}{ Knowledge } & \multicolumn{1}{c}{ Critical Thinking } \\
\hline Realist & $\begin{array}{l}\text { Assertions are Copies of an } \\
\text { external reality. }\end{array}$ & $\begin{array}{l}\text { Knowledge comes from an } \\
\text { external source and is } \\
\text { certain. }\end{array}$ & $\begin{array}{l}\text { Critical thinking is } \\
\text { unnecessary. }\end{array}$ \\
Absolutist & $\begin{array}{l}\text { Assertions are Facts that are } \\
\text { correct or incorrect in their } \\
\text { representation of reality. }\end{array}$ & $\begin{array}{l}\text { external source and is certain } \\
\text { but not directly accessible, } \\
\text { producing false beliefs. }\end{array}$ & $\begin{array}{l}\text { Critical thinking is a vehicle } \\
\text { for comparing assertions to } \\
\text { reality and determining their } \\
\text { truth or falsehood. }\end{array}$ \\
Multiplist & $\begin{array}{l}\text { Assertions are } \text { Opinions freely } \\
\text { chosen by and accountable } \\
\text { only to their owners. }\end{array}$ & $\begin{array}{l}\text { human minds and, therefore, } \\
\text { uncertain. }\end{array}$ & $\begin{array}{l}\text { Critical thinking is irrelevant. } \\
\text { Assertions are Judgments that } \\
\text { Evaluativist }\end{array}$ \\
& $\begin{array}{l}\text { Knowledge is generated by be evaluated and compared } \\
\text { human minds and is } \\
\text { according to criteria of } \\
\text { argument and evidence. }\end{array}$ & $\begin{array}{l}\text { uncertain but susceptible to } \\
\text { evaluation. }\end{array}$ & $\begin{array}{l}\text { Critical thinking is valued as a } \\
\text { vehicle that promotes sound } \\
\text { assertions and enhances } \\
\text { understanding. }\end{array}$ \\
\hline
\end{tabular}

Source: Kuhn, Cheney, and Weinstock (2000)

In terms of discussion, realist children consider critical thinking as non-essential because knowledge is understood as information obtained from an external source and is certain. Absolutist children assume that critical thinking is a means to determine whether a statement or a claim is right or wrong. Multiplist children consider that critical thinking is not relevant because they believe that everyone is entitled to their opinions. In other words, each idea could be right. Children begin to coordinate subjective and objective aspects of knowing only at the evaluativist level. Hence, discussion or critical thinking is regarded as an essential intellectual activity as a means of supporting claims and increasing understanding. 
The first question in the appendix indicates a multiplist level of epistemological thinking, characterized by the dominant subjective aspect of knowing (i.e., personal opinion). Based on this thinking, discussions are not required because each opinion could be right. Participants who agree with not discuss those issues are assumed to be at the multiplist level of epistemological thinking, indicating lower intellectual values. On the other hand, those who endorse discussion are regarded as individuals with high intellectual values. Only the evaluativist level consider discussion as an important intellectual activity. Their reasons reflected participants' evaluativist level.

\section{Results}

Initial descriptive analysis reveals the following percentages of people endorsing discussion in question one is much higher than in question two and three $(71 \%, 47 \%$, and $50 \%$, respectively). As different types of issues presented to the participants, this result indicates that differences in percentage between those questions could be attributed to the types of problems people face in the question. For all three questions, only $24 \%$ of the sample consistently endorsed discussion, while $76 \%$ of the sample only recommend discussion in one or two questions. Table 2 shows the reason for participants for endorsing discussion were categorized into three different groups. Only one group reflects an evaluativist level of epistemological thinking.

For question one, the first category consists of reasons that focus on issues (i.e., excessive use of social media, adolescent sexual involvement, and divorce), which were used as examples for the respondents. This reason does not show the characteristics of an evaluativist level of thinking. For example, the reason "discussion is needed so that problems would not get worse" (see Table 2, question one) does not provide information about the kind of thinking related to the value of discussion. This reason focuses solely on problems or issues. The second category focuses on the aim or importance of discussion to solve the problems or issues. These reasons are better than the first category because it explains the importance of discussion. However, these two categories still do not show the characteristics of an evaluativist level of thinking. The third category indicates the understanding of seeing discussion as an essential intellectual activity. It means the coordination of subjective and objective aspects of knowing. Discussion is needed, among others, for the following reason: "to compare different opinions and obtain the best one to solve problems." This type of response shows that students understand that people could have their own opinions (subjective aspect) but that the best idea must be supported by arguments and evidence (objective aspect).

The first category of the reasons given by participants in question two focuses only on the objective criteria of a good candidate. The second category reveals reasons that focus exclusively on subjective personal preference. The first and second categories do not indicate an evaluativist level of thinking, as the reasons do not coordinate the objective and subjective aspects of knowing. Responses that focus on objective criteria reflect an absolutist level of thinking, while reasons that focus on personal preference are based on a multiplist level of thinking. For instance, "Choices depend on individuals' preference" reflects the understanding that everyone could have their own opinion or choice as characterized by a multiplist level of thinking. The third category consists of reasons that integrate objective and subjective aspects of choices, indicating the evaluativist level of thinking. An example of such an idea includes: "If we like a candidate, but that person shows poor performance, we should not choose that candidate" (see Table 2, question two). The previous example shows that the child has tried to integrate the subjective personal preference and objective criteria (i.e., performance). Only a few participants provided reasons that focus on both personal preference and objective criteria.

The reasons in question three are classified in the same way as those in question one. As in question one, reasons that focus on issues and aim of the discussion were not based on an evaluativist level of thinking. For this question, it was hard to find reasons that show the 
characteristics of evaluativist thinking. Only one reason "to achieve a better understanding of the problem" (see Table 2, question three) can be classified as the reason that focuses on the essentials of discussion. The response shows that discussions are valued to enhance understanding.

Table 2

Reasons Given to the Intellectual Value Questions

\begin{tabular}{|c|c|c|c|}
\hline Question & $\begin{array}{l}\text { Levels of an } \\
\text { epistemological } \\
\text { understanding }\end{array}$ & $\begin{array}{l}\text { Focus of } \\
\text { reasons }\end{array}$ & Examples of reasons \\
\hline \multirow[t]{3}{*}{ One } & Absolutist & Issues & $\begin{array}{l}\text { Discussion is needed so that: } \\
\text { Other people will not experience problems. } \\
\text { Problems can be solved together. } \\
\text { Problems are not getting worse. }\end{array}$ \\
\hline & Absolutist & $\begin{array}{l}\text { Aim of } \\
\text { discussion }\end{array}$ & $\begin{array}{l}\text { Discussion is needed: } \\
\text { To find out the best solution. } \\
\text { To minimize problems. } \\
\text { To prevent bad things from happening. }\end{array}$ \\
\hline & Evaluativist & $\begin{array}{l}\text { The } \\
\text { essentials of } \\
\text { discussion }\end{array}$ & $\begin{array}{l}\text { Discussion is needed: } \\
\text { To compare different opinions and obtain the best } \\
\text { solution. } \\
\text { Other people's oninions could be better than ours }\end{array}$ \\
\hline \multirow[t]{3}{*}{ Two } & Absolutist & $\begin{array}{l}\text { Objective } \\
\text { criteria }\end{array}$ & $\begin{array}{l}\text { Candidate must have a common interest. } \\
\text { We must choose a candidate who shows leadership, } \\
\text { competence, and responsibility. } \\
\text { We must choose a candidate with a good vision and mission, } \\
\text { not because like or dislike. }\end{array}$ \\
\hline & Multiplist & $\begin{array}{l}\text { Personal } \\
\text { preference }\end{array}$ & $\begin{array}{l}\text { Other people may disagree with our choice. } \\
\text { Choices are based on individual judgment to candidates } \\
\text { Choices depend on individuals' favorites. }\end{array}$ \\
\hline & Evaluativist & $\begin{array}{l}\text { Objective } \\
\text { and personal } \\
\text { preference }\end{array}$ & $\begin{array}{l}\text { If we like a candidate, but he/she shows poor performance, } \\
\text { we should not choose him/her. } \\
\text { There are other criteria besides our personal preference. }\end{array}$ \\
\hline \multirow[t]{3}{*}{ Three } & Absolutist & Issues & $\begin{array}{l}\text { If the problem is ignored, there could be a war between } \\
\text { countries. } \\
\text { The world will be destroyed if nobody is concerned about } \\
\text { world peace. }\end{array}$ \\
\hline & Absolutist & $\begin{array}{l}\text { Aim of } \\
\text { discussion }\end{array}$ & $\begin{array}{l}\text { To solve the problem. } \\
\text { There must be a negotiation to achieve agreement. }\end{array}$ \\
\hline & Evaluativist & $\begin{array}{l}\text { The } \\
\text { essentials of } \\
\text { discussion }\end{array}$ & To achieve a better understanding of the problem. \\
\hline
\end{tabular}

\section{Discussion}

The current findings show that only $24 \%$ of the samples consistently endorsed discussion in all three questions. Meanwhile, in their study, Kuhn \& Park (2005) found 13\% Korean and 40\% Caucasian American middle school student samples who consistently endorsed discussion in all three questions. No Japanese middle school students consistently answered the questions. Among the middle school student samples, the percentage of Indonesian who consistently endorsed discussion is lower than the Caucasian American but higher than the Korean. Hence, a higher percentage indicates that more students perceive the value of intellectual activities.

Those percentage differences could indicate the differences in intellectual values between cultures, supporting the idea that intellectual values are rooted in culture. This idea 
could be associated with socio-cultural perspectives on cognitive development that the culture where one was raised predominantly determines the way one learns to think (Bjorklund, 2005). The interest to discuss various problems is more dominant in Caucasian Americans compared to Korean, Japanese, and Indonesian. It could be explained with the differences commonly found between individualistic and collective societies. In individualistic societies (e.g., United States, Canada), children are raised to become autonomous, confident, and assertive. In collective societies (e.g., China, Taiwan, Korea), children are raised to restrain their opinions and desires and to be more mindful of the need of older people, their family, and society (Shaffer, 2005). The upbringing of Caucasian American in an individualistic society could have made them more accustomed to express their opinions in any discussion with parents, teachers, or friends. As a result, they endorse discussion more to Korean, Japanese, and Indonesian students.

Differences in the percentage of sample who consistently endorsed discussion in all three questions were also found between Indonesian and Korean samples despite coming from the same collectivist background. Thus, further studies need to be conducted to confirm whether this difference is meaningful. This difference can perhaps be explained by the questions used to assess intellectual values. Korean sample responded questions from the original intellectual values questions about the death penalty, gun control, and medical care as examples of social issues in question one and candidates of political position in question two. On the other hand, the Indonesian sample responded to the adapted version that provides the excessive use of social media, adolescent sexual involvement, and divorce as examples of social issues and candidates of chairman of school organization in question two. It is possible that middle school students felt that everyday problems, such as those found in the adapted version, need to be discussed more than issues related to government policy and politics, as stated in the original version.

The result of this study also shows that most students choose to endorse discussion in question one, and around half of the students endorse discussion in question two and three. The percentage of students that endorse discussion in question one is much bigger than in the remaining two questions. It could be that the kind of issue also determined the choices students make. Students considered social problems in question one to be more critical to discuss than the school organization leader election in question two and world peace issue in question three. Students may often find the problems in question one (i.e., excessive use of social media, adolescent sexual involvement, and increase in divorce cases) in their own family, friends, or neighborhood.

Furthermore, all these issues are related to right and wrong, especially for Indonesian culture. For most Indonesians who are Muslims, sexual involvement outside of marriage and divorce is unacceptable (Shaffer, 2005). These two reasons may underlie the choices to endorse discussion in question one. The issue of world peace in question three may be considered as an essential problem too by students, but it happens in other countries. This issue is not a concrete problem that students can find in their surroundings. Thus, only half of the students think that it is essential to be discussed. Whereas students may consider the election of chairman of school organization issue in question two as a simple problem about which candidates students like so only less than half of the students endorse discussion.

The result described above indicates that the value of intellectual activities is perceived differently by middle school students in Indonesia, depending on the type of problem. Discussion, as an intellectual activity, is more valued when it involves real issues that happen around an individual. Students seem to perceive that discussion is vital to do when there are problems to be solved instead of used to enhance their understanding. This condition can be associated with which level of epistemological understanding the students reach. It has been described before that most reasons given by students are categorized into absolutist and multiplist level. Only a few reasons indicate an evaluativist level. Therefore, it can be said that most students in this study have not reached an evaluativist level. Before adolescents achieve 
the evaluativist level, they assume that critical thinking is irrelevant because all ideas are equally right (multiplist) or because facts are available to anyone who look for them (absolutist) (Kuhn, Cheney, et al., 2000). The result of a previous study confirms the epistemological level theory (Kuhn \& Park, 2005). Only a small percentage of students in Korea and Japan predominantly exhibit an evaluativist level of thinking. In contrast, most of the Caucasian American samples show an evaluativist level.

Intellectual value could be enhanced by involving in intellectual activities. (Kuhn, 2010) trained middle school students about argumentation and asked students what explicit knowledge they obtained from this activity. The students' responses included learning to hold emotion, listen, and provide reasons to support opinion. Those responses reflect students' perceived values of intellectual activities that were obtained after participating in argumentation training. Another study developed a computer-based training intervention in the ecology domain (Hefter et al., 2015). They found positive effects of the intervention on epistemic orientation, intellectual values, and conceptual knowledge.

The result of this study reflects the intellectual values of Javanese students. Various cultures and sub-cultures are existing in Indonesia. Therefore this study is not meant to describe all Indonesian middle school students' intellectual values. Future research needs to explore intellectual values and epistemological understanding in many other cultures in Indonesia.

\section{Conclusion}

Indonesian middle school students tend to perceive discussion as an important activity when facing real problems. This condition related to the level of epistemological understanding of the students. Most students still have an absolutist or multiplist level of an epistemological understanding. Thus, they do not value discussion as intellectual activities that are important to enhance their understanding of various issues or acquire new knowledge as perceived by evaluativist.

\section{References}

Abdurakhman, H. (2016). Menghafal itu bukan belajar (Memorizing is not learning). https://edukasi.kompas.com/ $\mathrm{read} / 2016 / 12 / 14 / 15245261 /$ menghafal.itu.bukan.belajar?page=all

Ackerman, P. L., Kanfer, R., \& Goff, M. (1995). Cognitive and noncognitive determinants and consequences of complex skill acquisition. Journal of Experimental Psychology: Applied, 1(4), 270-304. https://doi.org/10.1037/1076-898X.1.4.270

Arteche, A., Chamorro-Premuzic, T. C., Ackerman, P., \& Furnham, A. (2009). Typical intellectual engagement as a byproduct of openness, learning approaches, and selfassessed intelligence. Educational Psychology, 29(3), 357-367. https://doi.org/10.1080/01443410902927833

Bell, R., Smetana, L., \& Binns, I. (2005). Simplifying inquiry instruction. The Science Teacher, 72(7), 30-33.

Bjorklund, D. F. (2005). Children's thinking: Cognitive development and individual differences. Fourth edition. Belmont, CA: Wadsworth/Thomson Learning.

Cacioppo, J. T., Petty, R. E., \& Kao, C. F. (1984). The efficient assessment of need for cognition. Journal of Personality Assessment, Vol. 48, pp. 306-307. https://doi.org/10.1207/s15327752jpa4803_13

Chamorro-Premuzic, T., Furnham, A., \& Ackerman, P. L. (2006). Incremental validity of the typical intellectual engagement scale as predictor of different academic performance measures. Journal of Personality Assessment, 87(3), 261-268. 
https://doi.org/10.1207/s15327752jpa8703_07.

Hefter, M. H., Renkl, A., Riess, W., Schmid, S., Fries, S., \& Berthold, K. (2015). Effects of a training intervention to foster precursors of evaluativist epistemological understanding and intellectual values. Learning and Instruction, 39, 11-22. https://doi.org/10.1016/j.learninstruc.2015.05.002

Hevey, D., Thomas, K., \& Maher, L. (2012). Method effects and the need for cognition scale. The International Journal of Educational and Psychological Assessment, 12(1), 20-33.

Internation Test Commission. (2016). The ITC Guidelines for Translating and Adapting Tests (Second edition). [www.InTestCom.org]

Jeanrie, C., \& Bertrand, R. (1999). Translating tests with the international test commission's guidelines: Keeping validity in mind. European Journal of Psychological Assessment, 15(3), 277-283. https://doi.org/10.1027//1015-5759.15.3.277

Kuhn, D. (1999). A developmental model of critical thinking. Educational Researcher, 28(2), 16-46. https://doi.org/10.3102/0013189x028002016

Kuhn, D. (2001). How do people know? Psychological Science, 12(1), 1-8. https://doi.org/10.1111/1467-9280.00302.

Kuhn, D. (2010). Teaching and learning science as argument. Science Education, 94(5), 810824. https://doi.org/10.1002/sce.20395

Kuhn, D. (2010). What is scientific thinking and how does it develop? In U. Goswami. The Wiley-Blackwell Handbook of Childhood Cognitive Development, Second Edition, (July 2010), 497-523. https://doi.org/10.1002/9781444325485.ch19

Kuhn, D., Black, J., Keselman, A., \& Kaplan, D. (2000). The development of cognitive skills to learning support inquiry. Cognition, 18(4), 495-523. https://doi.org/10.1207/S1532690XCI1804

Kuhn, D., Cheney, R., \& Weinstock, M. (2000). The development of epistemological understanding. Cognitive Development, 15(3), 309-328. https://doi.org/10.1016/S08852014(00)00030-7

Kuhn, D., \& Park, S. H. (2005). Epistemological understanding and the development of intellectual values. International Journal of Educational Research, 43(3), 111-124. https://doi.org/10.1016/j.ijer.2006.05.003

Mascherek, A., \& Zimprich, D. (2011). Stability and change in typical intellectual engagement in old age across 5 years. The Journals of Gerontology, Series B: Psychological Sciences and Social Sciences, 67(3), 309-316. https://doi.org/10.1093/geronb/gbr101.

Mussel, P. (2010). Epistemic curiosity and related constructs : Lacking evidence of discriminant validity. Personality and Individual Differences, 49(5), 506-510. https://doi.org/10.1016/j.paid.2010.05.014

Shaffer, D. R. (2005). Social and personality development. Fifth edition. Belmont, CA: Thomson Wadsworth.

Slavin, R. E. (2014). Educational psychology: Theory and practice. Tenth edition. Harlow: Pearson Education Limited.

Stumm, S. Von, \& Furnham, A. F. (2012). Learning approaches: Associations with typical intellectual engagement, intelligence and the big five. Personality and Individual Differences, 53(5), 720-723. https://doi.org/10.1016/j.paid.2012.05.014 


\section{Appendix}

The Original Intellectual Values Questions (Kuhn, 2001):

1. Many social issues, like the death penalty, gun control, or medical care, are pretty much matters of personal opinion, and there is no basis for saying that one person's opinion is any better than another's. So there's not much point in people having discussions about these kinds of issues. Do you strongly agree, sort of agree, or disagree? (If disagree) What do you think?

2. Who you prefer as a candidate for a political position is pretty much a matter of personal preference. So there's not much point in people having discussions about political candidates. Do you strongly agree, sort of agree, or disagree? (If disagree) What do you think?

3. Some problems, like achieving world peace, are such difficult ones that they may not have a solution, just like scientists may never understand such difficult questions as the nature of matter. We have to accept that some things in life are too difficult to understand or change, and it's best not to worry too much about them. Do you strongly agree, sort of agree, or disagree? (If disagree) What do you think?

The Adapted Intellectual Values Questions:

1. Berbagai masalah sosial, seperti penggunaan media sosial yang berlebihan, pergaulan bebas di kalangan remaja, atau meningkatnya perceraian, adalah lebih merupakan pendapat pribadi, dan tidak ada dasarnya mengatakan bahwa pendapat seseorang lebih baik dibandingkan pendapat orang lain. Oleh karena itu tidak ada gunanya mendiskusikan masalah-masalah tersebut. Apakah anda sangat setuju, setuju, atau tidak setuju? (Jika tidak setuju) Apa pendapat anda?

2. Siapa yang anda sukai sebagai seorang calon ketua OSIS lebih merupakan masalah pilihan pribadi. Oleh karena itu tidak ada gunanya berdiskusi mengenai masalah tersebut. Apakah anda sangat setuju, setuju, atau tidak setuju?

(Jika tidak setuju) Apa pendapat anda?

3. Beberapa masalah, seperti mencapai perdamaian dunia, adalah masalah yang sulit yang mungkin tidak ada solusinya, sebagaimana kita yang mungkin tidak akan pernah memahami pertanyaan yang sulit seperti mengapa kejahatan selalu ada. Kita harus menerima bahwa beberapa hal dalam kehidupan terlalu sulit untuk dipahami atau diubah, dan sebaiknya tidak terlalu mencemaskan hal-hal tersebut. Apakah anda sangat setuju, setuju, atau tidak setuju? (Jika tidak setuju) Apa pendapat anda? 